\title{
The Complexities of Women Land Ownership in Northern Ghana
}

\author{
Millar Katherine Kaunza-Nu-Dem¹, Babatunde Tijani², David Millar², \\ Anafo Humphrey ${ }^{1}$ \\ ${ }^{1}$ University for Development Studies, Tamale, Ghana \\ ${ }^{2}$ Millar Institute for Transdisciplinary and Development Studies, Bolgatanga, Ghana \\ Email: kaunzakatherine@gmail.com,jamrockfarms@yahoo.com,millarad1@yahoo.com, \\ humphreywepare@gmail.com
}

Received 1 June 2016; accepted 21 August 2016; published 24 August 2016

Copyright (C) 2016 by authors and OALib.

This work is licensed under the Creative Commons Attribution International License (CC BY).

http://creativecommons.org/licenses/by/4.0/

(c) (i) Open Access

\section{Abstract}

Land issues have the potential to, and actually do generate a lot of conflicts and controversies in rural communities. In Northern Ghana, certain dilemmas, animated controversies, and conflicts about land rights, the resolution of which sometimes leads relatively innocuous compromise later manifest in several negative ramifications. For women in particular, the above negativities associated with land are even more pronounce and more protracted. This research adopted a case study approach to conduct this survey. The specific techniques used for data collection and analysis include: stratified group discussions, focus group discussions, key informant interview, phased assertion (confrontational dialogue), and critical arena analysis. The major findings include the fact that both men and women stated that land allocation to women is a regular affair now. It is the aspect of outright long-term ownership and user rights that are still very restricted. Since women do not sacrifice to the land her role in land sacrifices will be problematic. Women would prefer to acquire such formalized rights in their husbands' homes, with the understanding that they could pass rights so acquired to their sons. Because of the intricate nature of land and the complications therein, and for the avoidance of perpetual conflicts, the women opted for increasing user-rights rather than ownership or controls of land. The concept of ownership, in their local language, was very nebulous to the women. Some were quick to state that they never wanted to own land. The study thus recommended that the socio-cultural values and practices in the area were inimical to any reforms to mainstream women in land issues. An extensive education and re-education of communities, linked with exposing them to best practices elsewhere are recommended. An endogenous development approach is recommended for such an education. There is a need to strengthen dialogue between women and men on issues of land. When men appreciate the benefits of making land available to women it facilitates the ease of giving out land. Economic empowerment of women is also recommended as a way of making land more accessible to women. The women contend that when they have money or wealth in the form of livestock, these assets make it easier for them to either rent land or engage in some form of traditional land tenure arrangement to acquire land for farming purposes. 


\title{
Keywords
}

\section{Land Tenure, Women Land Conflicts, Ownership, Endogenous Development}

\author{
Subject Areas: Human Geography, Sociology
}

\section{Introduction}

The issue of land has always been seen as "an all men's affair". This is the perception that is purported of traditional land ownership and management systems and has become stereotypical or the mindset of many. Unfortunately this perception has made in-roads into formal discourses on land and even policies are not altogether clear on women and land issues. Most of the official pronouncements on land tend to restrict ownership to Chiefs and Tindaabas (traditional "ownerships"-institutions that are predominantly male). Then community, family and individually owned lands are another cluster of ownership arrangements and that subsumes that women are catered for (but not explicitly so) [1].

Very little effort exists in allowing women themselves to articulate their position in this matter. The historical ramifications that have led to these perceptions are not well known. What arrangements out of the ordinary are made by traditional institutions to cater for women cases with respect to land is unclear. The frustrations, marginalisation, and conflicts that have emerged out of the historical usurpation of women's rights to land need to be brought to the fore.

Recently there are projects and programme to address land issues in Ghana and in so doing streamline land administration. CARE International has become an active partner to this initiative. The fear exists, and genuinely so that if women issues are not drummed up in their various ramifications, they will once more be left out altogether, marginalised (by wholesale workshop approach where women have nominal representation), or be spoken for (also by a select group of women) without the voices of the poor and disadvantaged woman been heard.

\section{Land Issues in Perspective}

Several writers acknowledge the fact that land issues have the potential to; and actually do generate a lot of conflicts and controversies [2]-[5]. Even when a state has only limited ambitions of direct interference in land matters, land issues can be greatly affected by the State's ambition to organise and re-organise the local level structures [6] [7]. Thus, there is often an intimate linkage between the desire for increase in agricultural productivity by the state and the interference in land administration at the rural community level [5] [8]-[10]. In Northern Ghana, certain dilemmas animated controversies and conflicts about land rights; the resolution of which sometimes leads relatively innocuous compromise which later manifest in several negative ramifications. As posited by [11] [12], for the women in particular, the above negativities associated with land are even more pronounce and more protracted. [3] [5] state that women interests are undermined, their agendas are ignored, their ownerships and controls of land as a resource are undervalued.

Triangulating the findings with an earlier study we did with their male counterparts (unpublished) showed that at various stages local leadership has tried pragmatic efforts to deal with a number of dilemmas, conflicts, and controversies in associated with women and land tenure system:

- The men vehement ally argue for the fact that they prefer that the natural evolution of land tenure should not be interfered with, either on the one hand by introducing foreign principles and theories not understood by the people, or, by introducing issues of gender.

- Consequently, there were serious fears among the men that local chiefs and land holders would be subject to land speculation and ultimately be victims of alienation if women were brought into the equation.

- Giving women the absolute rights of ownership would tend to disrupt the socio-cultural fabric of the people, and so, too, would the indiscriminate allocation of land for women to cultivate.

- The men saw the Tindana as the only institution with administrative capacity to manage the land, and sufficient protect the interests of all, and since this institution is male dominated, land, by extension, is a male affair. 
- However, the men recongise the fact that, things are either changing or need to be changed as regards their lands. This change, they argue, should be gradual and should be within their cultural context in order to avoid the many conflicts that may arise leading to the dismembering of the society.

\section{Methodology}

A case study approach was adopted for this exercise [13] [14]. However, to make the cases fairly representative, the spread cover the Upper East Region as widely as possible. From the far east of the Region, Kanjaga and Chobsa were the communities interviewed in the Builsa District, and Pungu of Navrongo in the KassenaNankani District. In the Bolgatanga area, Kalbeo, and Nangodi were chosen. From Bawku West Bugri were visited.

A combination of methods used included:

- Stratified Group Discussions. This meant separating the men and women and interviewing the groups separately. In some cases they were brought together and made to confront one another and in others the findings remained separated.

- Focus Group Discussions. These were mixed groups of elderly men and women with land rights or potential rights to land.

- Key Informant Interview. A one-on-one interview with traditional institutions (men, women, and youth), elders, and some functionaries (also Government like teachers and extension staff from the area) living in the community.

- Phased Assertion, Confrontational Dialogue and Critical Arena Analysis had to be adopted to break initial barriers and mind-sets.

In whichever case, the findings were later processed in discussions by a larger group.

\section{Discussion of Findings from the Case Studies}

Our recent findings on women and land confirm our earlier research [15] and also the findings in Zimbabwe of [16], and work done by [17] in Southern Africa. The findings underscore the fact that traditional ties between rural people (also women) and land are not only material but also religious or spiritual. Land belongs to God ("Naawin", "Yini", Allfather), the ancestors or their spirits, founders of the lineage, clan or tribe interred therein, and the yet unborn.

To demonstrate this, landmarks such as certain hills, ponds, trees are named after ancestors whose spirits they honour. Every descendant (man or woman) is entitled to enough of this land to support his family. It is allotted, most often by the "Kosug-dana" (landowner—not necessarily the Tindana—one with spiritual responsibilities for especially Traditional Protected Lands (TPL)). Other forms of allotments are by family, family head, clan, or by individual as in husbands allotted land to their wives and sons.

It is important to state here that the Tindana is not necessarily synonymous to owners of land. Tindanas are the custodians of spiritual lands and trees, sacred lands and trees, and any unclaimed property that is found in the village. They perform all spiritual requirements of the land. Tindanas may double as agricultural land owners where they have land to farm on their own or they may be found borrowing land from others for farming purposes.

The tribal territories of land are guarded and protected by the spirits of the ancestors buried there, particularly by those of the oldest founding ancestors. These are often very powerful spirits who guide many aspects of the daily life of the family or tribe in order to keep harmony with the natural environment.

Land use allocations are by consultations. There are layers and levels of intensities of consultations. They might be simple and informal or formalised with sacrifices and other specialised performances by special persons (including spirit mediums). Change of "ownership of land" often goes through similar practices. This engenders the need to define ownership of, especially, rural lands.

Ownership of land for both men and women in the rural sector is, from OUR studies, a nebulous concept. Is there outright ownership even for the men? What do we mean by ownership and is there such an ownership concept among rural people (men and women)? How is this operationalised and how can we better understand and deal with the various nuances therein? How do we marry or reconcile the spiritual under-pinning of land with our material interpretations? These and many more are questions raised by our recent exercise into Women and land. 
This said, I now introduce some shades of ownership that I encountered in current work. The Study found out that the first position that is often generally taken is that women do not own lands in northern Ghana and that is final. The statement is made by both men and women that, “... we own the women or they own us. Not to talk about the land. This is no issue for discussion. It has been so and will continue to be so; period!!!” Breaking through this mind-set required tack and experience. With a bit of phased assertion and confrontational dialogue and also refereeing some critical arenas, the following findings have been an eye-opener for the interviewer and the respondent, and a rich occasion for learning for all including the youth who sat round to listen in.

\subsection{Ownership}

The following understandings of land ownerships were revealed (these were not any very different from the men):

1) Absolute and permanent ownership. Here the occupant has all the rights to use the land and the trees for whatever purpose including out-right sale in consultation with family members.

2) Absolute ownership of land but not the trees. Except for the trees, the occupant has all the rights to use the land for whatever purpose including out-right sale in consultation with family members.

3) Ownership of the land in so long as the occupant is using for agricultural purposes or the purpose for which it is designated for only. For all other uses the occupant has to consult the owner.

4) Temporary ownership. This is as seasonal use of land. After each season the land goes back to the owner.

5) Sale of land is rare. Symbolic exchanges occur to guarantee land use rights.

6) Obligations for consultations spread over all titled and non-titled arrangements.

\subsection{Why Do Women Not Own Land?}

The initial responses to this question by the women themselves include the following:

- Women used not to be in full-time farming like they do today. They used be supportive to their husbands and therefore did not need land on their own.

- Because they are not permanent members of their father's homes.

- Because they have come from a different place to be at their husbands homes.

- Because their permanency cannot be guaranteed.

- Because they are not good managers so if entrusted with a valuable commodity like land may misuse it.

- Women cannot and do not sacrifice to the spirits of land hence do not satisfy the ultimate qualifications to own land.

\section{Case Probes}

\subsection{Among the Builsa}

There are rare instances when women own land:

- When a woman comes from the Tindana family, she has right to land ownership and can and do claim land when they are still in their father's home. This right, which temporary, is lost when she decides to marry and she cannot also pass it on in old age or death.

- There is guaranteed access to land (by the ancestral spirits) for all members of the family (male or female).

- There is also guaranteed equitable sharing of benefits from land (by the ancestral spirits) to all members of the family.

- Communal lands and traditionally protected lands (shrines, groves, sacred places and trees) are owned by all.

- Because of labour constraints, land requirements of women are usually very small.

- There are certain cultural practices (including sacrifices) that are done to publicly declare that a piece of land belongs to a woman. Even then she does not own the trees and confiscations of such lands, though rare, are possible.

- When a man has all daughters, female headed homes, and widows have their own lands but have to consult the male members of the family on its use.

- These day women are given productive lands by their husbands to themselves. If husband dies the land remains the woman's own. But when the woman dies the one of the Brothers of the man or the man who performs her funeral takes that land. Ownership of this cannot be passed on automatically. 
- No performance is required for a husband to give part of his "Nagang” (land in front of his house that is his own — not family or communal land) to his wife. Proof of ownership is for her to continuously cultivate that piece over time.

- The Builsas also see land as an aspect of "power and authority". Men do not want see some of this power taken away from them and it is also a potential for conflict to have two lines of authority as reflected in land ownership.

\section{As to Their Views of the Status Quo}

They are quick to mention that now women are farmers not helpers and will want to have their own lands distinctively identified. They are also quick to say that the situation is not like before when men do not give women land. Now they give. They give poor lands and sometimes very rich lands. In some cases they women say which piece they prefer. This is because the men have noticed the women's ability to bring in income for the use of the family thus liberating the man's own for his personal use.

This notwithstanding, women will want to maintain the situation as it is. Why?

- They cannot meet the sacrifices and the spiritual requirements of the land.

- They are not good managers of land and mismanage it.

- The risk is that the men might give them so much land that they cannot cultivate or exploit their labour by allocating them land and sit back to watch them suffer.

The men welcomed the idea of formalising women ownership of the land. Why?

- The inheritance system might deny your wife and children of land when you die. Hence there is the need to guarantee that they have property.

- It is not only for today. The girls now go to school and therefore are or will be different so we need to prepare for some securities for them and land is one major security.

- What about the sacrifices that have to be done on the by the men only? The reply is that things are changing these days. Some of their Brothers have land but are down south for many years so not sacrifices are done to those lands.

When asked where they would prefer to acquire such formalised land rights, the women said in their husbands' homes.

\subsection{Among the Kalbeo People}

There is the need to mention a special phenomenon here. When a male family head realises that he has only women in his line, in order to perpetuate that line one of the girls is chosen to sit at home and have children for the family. Also a well to do woman might keep other women as wives and they intend have children for her. In these instances the woman is seen as a man and therefore owns land and has land rights like all other men in the community. Hence is easy to find female "Kusog Daanas". Also if the Tindaana family is left with only women, one of them becomes the Tindaana and performs all the duties of the Tindaana that a man would.

Here too land allocation/sharing is done once.

Rare instances when women own land include:

- When a woman comes from the Tindana family, she has right to land ownership and can and do claim land when they are still in their father's home. This right, which temporary, is lost when she decides to marry and she cannot also pass it on in old age or death.

- There is guaranteed access to land (by the ancestral spirits) for all members of the family (male or female).

- There is also guaranteed equitable sharing of benefits from land (by the ancestral spirits) to all members of the family.

- Communal lands and traditionally protected lands (shrines, groves, sacred places and trees) are owned by all.

- When a woman owns the lands she owns the trees standing on it.

- The woman has a free hand to use the land she owns for whatever purpose including construction and sale.

- When Brothers share land (which they do very often these days), when one dies and the children are still young the land belongs to the wife. It cannot be taken from here by any family member.

- When a man has all daughters, female headed homes, and widows have their own lands but have to consult the male members of the family on its use. Also once a woman is accepted or given the responsibility as the head of the home, she automatically controls all land. It was put this way, “... once you control the men, you also control the land". 
- When the woman's land holding is too large, she is free to sub-let portions of it and the royalties are paid to her directly not to any male member of the family.

- When a man dies, his land holdings are available to any male member of the family provided that person assumes responsibility for the upkeep of the wife and children of the previous owner. When there is no one prepared to shoulder such responsibility, the land remains the property of the woman and her kids. First the woman takes over ownership until the sons are grown enough to take it over. But if she has only daughters, it becomes the woman's own land.

\section{As to Their Views of the Status Quo}

The women noted here too that these days women are farmers not helpers and will want to have their own lands distinctively identified.

The men agree with the women and added that if only it is to formalise what obtains now not to introduce new conflicts.

Both the men and women take the position is that land allocation to women is a regular affair now. It is the aspect of outright ownership that needs regularisation.

The issue of sacrifice to the land was raised and discussed. Since women do not sacrifice to the land what happens to the woman's land? The conclusion was that since the husband will be alive or there will be male members sacrificing to family lands in general at the beginning of the rainy season, this sacrifice will be all encompassing. It will not leave out the woman's land, more so if the woman makes a contribution to the sacrifice by offering some of her harvest.

When asked where they would prefer to acquire such formalised land rights, the women said in their husbands' homes.

\subsection{Among the Nabd of Nangodi}

\subsubsection{Agricultural Land}

- An unmarried woman can access land control it and own it as long as you live.

- Can ask an individual for a small piece of land to farm on but after your death it could be reclaimed depending on how you children will be nice to them. A group of female farmers can ask the Tengdana for land, control it, own it, and benefit from it; but when the group ceases to exist the land reverts to the Tengdana.

- When a woman's husband dies the land the man used as his farm is taken back by the family head. The family head then gives a portion of the land to the widow to use until she also dies.

- When the land is given to the woman and her husband by the Tengdana, the widow will still have access to the land without having to ask her husband's relatives for permission to use it. The land becomes the property of the widow and her husband's children.

- If the land belongs to the woman's husband's family the family head will be in control when her husband dies.

- If the land belonged to the extended family of the widow's husband the family head will own the land that the widow and her husband owned and used. If the land was owned by the woman and her husband because the Tengdana gave it to them the widow will be in ownership of the land when her husband dies.

- The benefits of agricultural land on which a widow farms are for the widow and her children if she has any.

\subsubsection{Forests and Fuel Wood}

- Have access to firewood from our community woodlots.

- Fuel woodlands that were on our family land were controlled by us.

- Fuel wood land on our father's land was controlled by our family. However fuelwood lands that belong to the entire village was owned by Tengdana. The forest reserve was owned by the Tengdana.

- Bebefits include, cooking, collecting grass for thatch roofs and mats.

\subsubsection{Fruit Tree Land}

- Have unimpeded access to communal fruit tree lands.

- Fruit tree on other people's land was not accessible.

- Have no control over fruit tree lands.

- Fruit tree lands on our father's land belonged to our father; those in the communal areas belonged to the 
Tindana.

- The benefits of what I pick from fruit tree land are for our family.

\subsubsection{Reserve Lands for Future}

- Women have very limited access to reserve lands with no controls over them.

- Reserve lands are for the community and are owned and managed by the Tengdana.

- If the farms women are currently using are not productive we will have virgin lands to cultivate.

\subsubsection{Construction and Housing}

- Have access to land for construction through our husband.

- Women's control is dependent on our husband. For as long as he does not take the land back I am in control of it.

- For as long as the man does not take the land back I am the owner.

- Benefits are shared with the husband.

\section{Conclusions}

In conclusion, this study noted from the women that:

- Since women in these days are farmers and not helpers, they will want to have their own lands distinctively identified. They are also quick to say that the situation is not like before when men were reluctant to give women land. Now they give but they give very poor agricultural lands.

- In a few cases, the women are given the opportunity to decide which piece they prefer. This is because the men have noticed the women's ability to bring in income for the use of the family thus reserving the man's own for his personal use. Some do so in anticipation of the women investing in fertility improvements of those lands such that when the men are taking them back then their value is enhanced.

- Both men and women take the position that land allocation to women is a regular affair now. It is the aspect of outright long-term ownership and user rights that are still very restricted.

- The issue of sacrifice to the land was raised and discussed. Since women do not sacrifice to the land what happens to the woman's land? The conclusion was that since the husband will be alive or there will be male members sacrificing to the family lands in general at the beginning of the rainy season, this sacrifice will be all encompassing. It will not leave out the woman's land; more so if the woman makes a contribution to the sacrifice by offering some of her harvest.

- When asked where they would prefer to acquire such formalized rights, the women said in their husbands' homes, with the understanding that they could pass rights so acquired to their sons.

- Because of the intricate nature of land and the complications therein, and for the avoidance of perpetual conflicts, most of the women interviewed opted for increasing user-rights rather than ownership or controls of land.

- To support this position they argued that their major crops are annuals and not perennials (vegetables and legumes). This allows them to navigate through the short-term tenets that they are forced into by their male counterparts.

- The concept of ownership was very nebulous to the women. Discussing it with the local dialect caused some apprehension by the women. Some were quick to state that they never wanted to own land. They even queried their dual identity, belonging to their fathers' homes and their husbands' homes. Which should be the basis for allodia rights?

\section{Recommendations}

For the way forward the following recommendations were made:

- The socio-cultural values and practices as obtained now are inimical to any reforms to mainstream women in land issues. An extensive education and re-education of communities; linked with exposing them to best practices elsewhere is recommended. An Endogenous Development Approach [18] is recommended for such an education.

- There is the need to strengthen dialogue between women and men on issues of land. When men appreciate the benefits of making land available to women it facilitates the ease of giving out land. Workshops and fora 
were recommended as opportunities through which intensive gender based advocacy activities can be implemented in a participatory fashion to disabuse the minds of men and women on gender-based discrimination on land.

- Economic empowerment of women was also proposed as a way of making land more accessible to women. The women contend that when they have money or wealth in the form of livestock, these assets makes it easier for them to either rent land or engage in some form of traditional land tenure arrangement to acquire land for farming purposes. Alternative livelihood schemes (beekeeping, shea butter and groundnut processing, or rearing of small ruminants and poultry etc.) were therefore proposed as activities that can make this objective a reality.

\section{References}

[1] Fortes, M. (1945) The Dynamics of the Clanship among the Tallensi. Being the First Part of an Analysis of the Social Structure of the Trans-Volta Tribe. International African Institute/Oxford University Press, London, 171-190.

[2] Ninsin, K. (1989) The Land Question since the 1950s. In: Hansen, E. and Ninsin, K., Eds., The State, Development and Politics in Ghana, CODESRIA, London, 165-183.

[3] Kasanga, K. (1994) Land Tenure Systems and Ecological Degradation in Northern Ghana. What Role for Local Authorities? Royal Institution of Chartered Surveyors (“Our Common Estate”-Programme), London.

[4] Nyari, B.S. (1995) Interface of the Traditional and the Modern Land Tenure Systems in the Urban Land Market and Its Effects on the Urban Development Process. A Study of the Land Reform Process in Ghana. MA Dissertation ISS, The Hague.

[5] Lund, C. (2002) Negotiating Property Institutions. On the Symbiosis of Property and Authority in Africa. In: Juul, K. and Lund, C., Eds., Negotiating Property in Africa, Heinemann, Portsmouth, 11-44.

[6] Bening, R.B. (1973) Indigenous Concepts of Boundaries and Significance of Administrative Stations and Boundaries in Northern Ghana. Bulletin of the Ghana Geographical Association, 15.

[7] Bening, R.B. (1996) Land Ownership, Divestiture and Beneficiary Rights in Northern Ghana. Konrad Adenauer Foundation, Decentralisation, Land Tenure and Land Administration in Northern Ghana.

[8] Roncoli, M.C. (1994) Managing on the Margins: Agricultural Production and Household Reproduction in NorthEastern Ghana. Ph.D. Dissertation, State University of New York, Binghampton.

[9] Lentz, C. (2000) Contested Identities: The History of Ethnicity in North-Western Ghana. In: Lentz, C. and Nugent, P., Eds., Ethnicity in Ghana, The Limits of Invention, MacMillan Press, London, 137-161. http://dx.doi.org/10.1007/978-1-349-62337-2_7

[10] Wardell, D.A., Reenberg, A. and Tøttrup, C. (2003) Historical Footprints in Contemporary Land Use Systems: Forest Cover Changes in Savanna Woodland in the Sudano-Sahelian Zone. Global Environmental Change, 13, 235-254. http://dx.doi.org/10.1016/S0959-3780(03)00056-6

[11] Alhassan, R.I. (1996) Traditional Land Tenure System in the Northern, Upper East and Upper West Regions-Similarities, Differences and Modern Trends. Konrad Adenauer Foundation, Decentralisation, Land Tenure and Land Administration in Northern Ghana.

[12] Daanaa, H.S. (1996) Interest in Land in Northern Ghana-A Historical Review of Legal Issues. Konrad Adenauer Foundation, Decentralisation, Land Tenure and Land Administration in Northern Ghana.

[13] Yin, R.K. (2003) Case Study Research. 3rd Edition, Sage, Thousand Oaks.

[14] Creswell, J.W. (2007) Qualitative Inquiry and Research Design: Choosing among Five Approaches. 3rd Edition, Sage, Thousand Oaks.

[15] Abu, A. and Millar, D. (2006) Land Natural Resources and Spirituality: Policy Implications on Rural Livelihoods in the Northern Regions of Ghana. Centre for Cosmovision and Indigenous Knowledge Conference, 24-29 July 2006, Printed by Communication and Media for Development, Accra.

[16] Gonese, C. (1999) Culture and Cosmovision of Traditional Institutions in Zimbabwe. In: Haverkort, B. and Hiemstra, W., Eds., Food for Thought, Zed Books, England, 76-84.

[17] Huizer, G. (1991) Indigenous Knowledge and Popular Spirituality: A Challenge to Developmentalists. Paper for International Workshop “Agricultural Knowledge Systems and the Role of Extension”, Bad Boll University of Hohenheim, 21-24 May 1991.

[18] Millar, D. (2014) Endogenous Development: Some Issues of Concern. Development in Practice. Routledge. Techset Composition, India. 
Submit or recommend next manuscript to OALib Journal and we will provide best service for you:

- Publication frequency: Monthly

- 9 subject areas of science, technology and medicine

- Fair and rigorous peer-review system

- Fast publication process

- Article promotion in various social networking sites (LinkedIn, Facebook, Twitter, etc.)

- Maximum dissemination of your research work

Submit Your Paper Online: Click Here to Submit

Contact Us: service@oalib.com 